\title{
Plant Poisoning Containing Hydrocyanic Acid in Cattle in Southern Brazil
}

\author{
Anderson Gris', Lucas Henrique Bavaresco ${ }^{2}$, Fernanda Felicetti Perosa' ${ }^{2}$, Teane Milagres Augusto Gomes ${ }^{2,5}$, \\ Nei Fronza ${ }^{3}$, Juliano Rossi de Oliveira ${ }^{3}$, Vanessa Peripolli ${ }^{4}$, \\ Cesar Rodrigo de Souza Surian ${ }^{5}$, André Luís de Gasper ${ }^{6}$ \& Ricardo Evandro Mendes ${ }^{2,5}$
}

\begin{abstract}
Background: Cyanogenic plants accumulate cyanogenic glycosides and release hydrocyanic acid (HCN). In Brazil, there have been reports of several plants that cause $\mathrm{HCN}$ poisoning in animals and lead to a fast death with few clinical signs and lesions on post mortem examination. Some cultivars of Cynodon spp. grasses cause HCN poisoning in cattle in Brazil. The objectives of this work were to report the occurrence of deaths by HCN poisoning in cattle as diagnosed by the veterinary pathology laboratory, describe the quantity of $\mathrm{HCN}$ in some cultivars of Cynodon spp., as well as, to describe one cultivar of genus Cynodon never reported as poisonous.

Materials, Methods \& Results: The archives of the Veterinary Pathology Laboratory (LPV) at the Concórdia Campus of the Instituto Federal Catarinense (IFC) were reviewed, seeking cases with a diagnosis of hydrocyanic acid poisoning in cattle after post mortem examination. The amount of HCN present in some cultivars of the Cynodon genus was quantified due to the high frequency of poisoning cases. From the 1,235 post mortem examinations of cattle $28(2.27 \%)$ were diagnosed with spontaneous hydrocyanic acid poisoning, 17 cases $(60.7 \%)$ due to ingestion of Prunus sp. or Manihot sp., and 11 cases (39.3\%) of Cynodon dactylon ingestion. Most animals were found dead, normally having presented no clinical signs. Macroscopic evaluation mainly showed a severe amount of unchewed and undigested leaves or grass mixed in the ruminal content presenting a bitter almond odor. It was possible to infer that, among cultivars of the Cynodon genus, Florakirk showed the highest levels of HCN compared $(P<0.05)$ with Star of Puerto Rico, Tifton 68, Tifton 44, and Coast-Cross. Furthermore, Tifton 85 and Jiggs showed undetected levels of HCN. Leaves showed the highest HCN levels when comparing different parts of the plant. Regarding conservation methods, hay showed undetectable levels of HCN.

Discussion: To the best of our knowledge, this work is the first description of HCN poisoning in cattle due to ingestion of Cynodon dactylon cultivar Florakirk. This condition is described with a fast-clinical course, with animals found dead with no premonitory clinical signs. Poisoned animals did not develop macroscopic or microscopic specific lesions. Poisoning can be suspected when animals die suddenly, with absence of lesions under necropsy, and large amounts of unchewed and undigested leaves or grass inside their forestomaches. The diagnosis can be established performing the Picrosodic paper test, either in the pasture, or in the ruminal content. Occasionally however, HCN can go undetected when this chemical compound volatilizes between death and necropsy after several hours. Of all the Cynodon cultivars evaluated, Florakirk was the most dangerous for animals. In contrast, Tifton 85 and Jiggs released no HCN. Leaves were the part of the plant presenting the highest concentration of HCN. This is a defense mechanism that the plant develops against the ingestion by animals. This condition can cause great economic losses to farmers with the loss of animals and the need for prevention by using cultivars without HCN or hay, as $2.27 \%$ (28) of deaths diagnosed by the Veterinary Pathology Laboratory in the west of Santa Catarina, Brazil, were due to HCN poisoning. Notably, Florakirk cultivar was identified as the most dangerous cultivar tested, with higher levels compared with Tifton 68. The Star of Puerto Rico cultivar showed similar levels of HCN as Tifton 68. Both cultivars are commonly cultivated in many farms in the south of Brazil.
\end{abstract}

Keywords: HCN, prussic, Florakirk, Cynodon dactylon, hay. 


\section{INTRODUCTION}

When cyanogenic glycosides, accumulated in cyanogenic plants, are submitted to enzymatic hydrolysis or when the damaged plant tissue (chewed or digested by bacteria) comes into contact with hydroxynitrile lyase, hydrocyanic acid, also known as prussic acid (HCN) is released [8].

$\mathrm{HCN}$ is rapidly absorbed when released in the forestomaches of ruminants, causing the inhibition of cellular respiration by binding with a trivalent iron in intracellular oxidative enzymatic systems. This leads to a decrease in energy production and cytotoxic hypoxia, progressing to cellular death [12,21].

In Brazil, there are reports of several plants that cause $\mathrm{HCN}$ poisoning in animals, all of them leading to fast death, with few clinical signs and lesions on post mortem examination [21]. One of the most common genera of pasture in Brazilian territory is Cynodon spp., which is described three species naturalized, that have good quality and capacity to be adapted. These characteristics have made these plants quite attractive to farmers [16,23] despite the potential for hydrocyanic acid poisoning.

In Brazil, $\mathrm{HCN}$ poisoning by spontaneous intake of Cynodon spp. grasses by cattle has been described [21]. Additionally, cases that occur due to the ingestion of Tifton 68 [9-10] and star grass [15] have been reported as well. Among other plants, Prunus myrtifolia (sphaerocarpa) and Manihot sp. were already known as potentially deadly [21]. Therefore, the objectives of this work were to report the occurrence of deaths by $\mathrm{HCN}$ poisoning in cattle as diagnosed by the Veterinary $\mathrm{Pa}-$ thology Laboratory, and describe the quantity of $\mathrm{HCN}$ in some cultivars of Cynodon spp., including cultivars never reported as potentially presenting $\mathrm{HCN}$.

\section{MATERIALS AND METHODS}

\section{Methodology}

Data from the archives of the Veterinary Pathology Laboratory (LPV) at the Instituto Federal Catarinense (IFC), Campus Concórdia, were reviewed, evaluating cases with the diagnosis of hydrocyanic acid poisoning in cattle after post mortem examinations. Data such as images and the description of breed, sex, age, municipality, year, history, and macroscopic and microscopic findings were evaluated.

In the post mortem examination, organ samples were systematically gathered, fixed in $10 \%$ buffered formalin $^{1}$, and routinely processed. Tissues were embedded in paraffin ${ }^{2}$ wax, cut in 3 -microns thick sections, and stained with hematoxylin and eosine ${ }^{2}$. Samples of ruminal content and of the grasses and/or leaves of the plants were collected for the Picrosodic paper test.

The Picrosodic paper test was performed [21]. It consists of a strip of white paper soaked in Picrosodic solution, composed of $5 \mathrm{~g}$ sodium carbonate ${ }^{3}$ and 0.5 g picric acid ${ }^{4}$ dissolved in $100 \mathrm{~mL}$ distilled water. The leaves or grass were macerated and placed in lidded plastic bowls, where the paper strip was placed and remained freely suspended above the plant material. In some cases, the plant material was replaced by ruminal content or muscle. The plastic bowl was held upright and the reaction was observed for one hour. The intensity of the reaction to the Picrosodic paper test was considered positive when the paper acquired a red-brick color.

\section{Quantification of hydrocyanic acid}

The samples of the Cynodon spp. cultivars were obtained from the agrostological field of the IFC, originated from a germplasm bank. The evaluated cultivars were Coast-cross (Cynodon dactylon), Tifton 68 (Cynodon nlemfuensis), Tifton 85 (Cynodon nlemfuensis), Tifton 44 (Cynodon nlemfuensis), Florakirk (Cynodon dactylon cultivar Florakirk), Jiggs (Cynodon dactylon), and Star of Puerto Rico (Cynodon nlemfuensis). The samples from the agrostological field of the IFC were harvested considering the suitable age and size for cattle to graze. Three harvests were performed for each cultivar with an interval of seven days between harvests.

The samples were identified and selected according to the structures to be used: leaf, stem, in natura whole plant, and hay. Haymaking was carried out in an oven and dried until obtaining approximately $15 \%$ of dry matter. Quantification was performed for each cultivar sample [11]. Hydrocyanic acid extractions were conducted in a lidded plastic bowl where the samples were macerated in particles measuring 1 to $2 \mathrm{~cm}$ in length. A strip of white paper soaked in Picrosodic solution was placed over the bowls of all treatments, including a negative control (with no content, just the strip of white paper soaked on Picrosodic solution). The bowls were then incubated in an oven at $37^{\circ} \mathrm{C}$ for $16 \mathrm{~h}$.

After incubation, $1 \mathrm{~cm}^{2}$ of each stripe was submerged in $5 \mathrm{~mL}$ of distilled water for $60 \mathrm{~min}$, in 
an oven at $37^{\circ} \mathrm{C}$. Subsequently, the absorbance of the solution was determined using a spectrophotometer, at a wavelength of $510 \mathrm{~nm}$. It was possible to calculate the amount of hydrocyanic acid in milligrams per kilogram $(\mathrm{mg} / \mathrm{kg})$, based on the result of the absorbance, according to the equation [11] $(\mathrm{HCN} \mathrm{mg/kg} \mathrm{=}$ $396 *$ absorbance*100/ Z [Z is the weight of the sample in milligrams]).

$\mathrm{HCN}$ was not measured in samples from areas diagnosed with outbreaks due to the significant difference in farm management, specially fertilizing regimes, type of soil, and grazing pressures. These factors would compromise results and comparisons. On the other hand, all samples measured from the agrostological field of the IFC were subjected to the same management, allowing the comparison of the results. Another reason is that outbreaks occurred in different years, and samples would be affected by different weather, also compromising the correlations.

\section{Data analysis}

The results of the quantification of $\mathrm{HCN}$ were tabulated and analyzed statistically using the Statistical Analysis System software ${ }^{5}$ as a completely randomized design. The HCN data were submitted to the ShapiroWilk and Levene normality tests. When data did not show a normal behavior, the NPAR1WAY procedure and the Kruskal Wallis test were used to analyze the part of the plant. The effect of the cultivar was evaluated using the GLM procedure, transforming the data (logarithmic transformation) since they were not homogenous. The means were compared by Tukey's test $(P<0.05)$.

\section{RESULTS}

Of the 1,235 bovine necropsies conducted in the Veterinary Pathology Laboratory (LPV), 28 $(2.27 \%)$ were diagnosed as hydrocyanic acid poisoning. Different plant species were indicated as the source, 15 (53.6\%) due to the ingestion of Prunus sp., $11(39.3 \%)$ due to Cynodon sp., and $2(7.1 \%)$ due to Manihot sp. Most deaths (24) occurred in outbreaks and 4 as isolated cases. Table 1 describes the stratification of municipalities, number of dead animals, year, number of animals per batch, species of cyanogenic plant, and mode of poisoning. All cases were diagnosed in the west of Santa Catarina.

The animals involved in the reported cases were dairy cattle $(85.7 \%)$, female (100\%), and adult (96.4\%). In most cases, $57.1 \%$ (16/28), farmers found the animal dead, always near the pasture or broken branches of Prunus sp. contaminating the pasture [Figure 1].

When the clinical course was extended, owners reported that the animals presented ataxia (11/28), paddling movement (5/28), acute dyspnea (4/28), drooling (4/28), and staggering when walking (1/28). The clinical course in one of the outbreaks extended for $3 \mathrm{~h}$, from the first view of clinical signs and the last animal that evolved to death. Despite the clinical signs, most animals evolved to death in minutes.

Severe amount of unchewed and undigested leaves or grass mixed in the ruminal content (23/28) [Figure 2] was observed in the macroscopic examination. Other findings consisted of a bitter almond odor (23/28), petechiae in the mucosa of the trachea (4/28), large amounts of Manihot esculenta shell (2/28), and non-clotting of bright red blood (1/25) [Figure 3]. The macroscopic or microscopic examination showed no other lesions.

The Picrosodic paper test was performed in $85.7 \%(24 / 28)$ of the cases. The ruminal content and pasture were positive in $75 \%$ (18/24) of the cases. Only the pasture was positive in the others 6 cases $(25 \%)$ [Figure 4]. Furthermore, the skeletal muscle was also positive in 4 cases $(16.67 \%)$. Picrosodic paper test was not performed in 2 outbreaks, where 4 animals (16.67\%) were subjected to post mortem examination, because a large amount of undigested Prunus sp. leaves was found mixed in the ruminal content and the extensive description of this tree shows cyanide glycosides.

\section{Quantification of hydrocyanic acid}

The hydrocyanic acid quantification allowed the conclusion that some cultivars of both species, Cynodon dactylon and Cynodon nlemfuensis, could release HCN. A comparison of the results of each analyzed cultivar (Figure 5) in the whole plant (stem and leaves) showed that Florakirk $(119.7 \mathrm{mg} / \mathrm{kg} \pm$ 58.0) presented the highest levels of $\mathrm{HCN}(P<0.05)$. Star of Puerto Rico $(111.7 \mathrm{mg} / \mathrm{kg} \pm 56.4)$ and Tifton $68(34.2 \mathrm{mg} / \mathrm{kg} \pm 30.1)$ showed intermediate levels of HCN, presenting higher levels $(P<0.05)$ than Tifton $44(18.7 \mathrm{mg} / \mathrm{kg} \pm 24.6)$ and Coast-Cross $(19.7 \mathrm{mg} / \mathrm{kg} \pm$ 21.8). Moreover, Tifton 85 and Jiggs released no HCN using the methodology applied in this study.

Statistically, the leaves $(54.7 \pm 47.31)$ presented $(P<0.05)$ more HCN than the stem $(32.1 \pm$ $48.82)$ and total in natura plant $(39.1 \pm 55.94)$. When evaluating the hay made from the whole plant, no cultivar showed any detectable levels of $\mathrm{HCN}$. 
Table 1. Stratification of cities, number of deaths and of animals of the batch, species of cyanogenic plant and mode of poisoning.

\begin{tabular}{|c|c|c|c|c|}
\hline City & Deaths & Total* & Plant & Poisoning \\
\hline Concórdia & 1 & NI & $\begin{array}{l}\text { Prunus myrtifolia } \\
\text { (sphaerocarpa) }\end{array}$ & $\begin{array}{c}\text { Contamination } \\
\text { of pasture }\end{array}$ \\
\hline $\begin{array}{l}\text { Alto Bela } \\
\text { Vista }\end{array}$ & 1 & NI & Cynodon dactylon & Pasture \\
\hline Concórdia & 3 & NI & $\begin{array}{l}\text { Prunus myrtifolia } \\
\text { (sphaerocarpa) }\end{array}$ & $\begin{array}{c}\text { Contamination } \\
\text { of pasture }\end{array}$ \\
\hline Concórdia & 4 & 12 & $\begin{array}{l}\text { Cynodon dactylon } \\
\text { cultivar Florakirk }\end{array}$ & Pasture \\
\hline Irani & 5 & NI & $\begin{array}{l}\text { Prunus myrtifolia } \\
\text { (sphaerocarpa) }\end{array}$ & $\begin{array}{c}\text { Contamination } \\
\text { of pasture }\end{array}$ \\
\hline Concórdia & 3 & 14 & $\begin{array}{l}\text { Prunus myrtifolia } \\
\text { (sphaerocarpa) }\end{array}$ & $\begin{array}{c}\text { Contamination } \\
\text { of pasture }\end{array}$ \\
\hline Peritiba & 1 & NI & Cynodon dactylon & Pasture \\
\hline Peritiba & 1 & NI & Cynodon dactylon & Pasture \\
\hline Concórdia & 4 & 10 & $\begin{array}{l}\text { Cynodon dactylon } \\
\text { cultivar Florakirk }\end{array}$ & Pasture \\
\hline Concórdia & 2 & 30 & Manihot esculenta & Feed base \\
\hline Concórdia & 3 & 17 & $\begin{array}{c}\text { Prunus myrtifolia } \\
\text { (sphaerocarpa) }\end{array}$ & $\begin{array}{c}\text { Contamination } \\
\text { of pasture }\end{array}$ \\
\hline
\end{tabular}

*Total Batch; NI: not informed or not recorded in the archives.

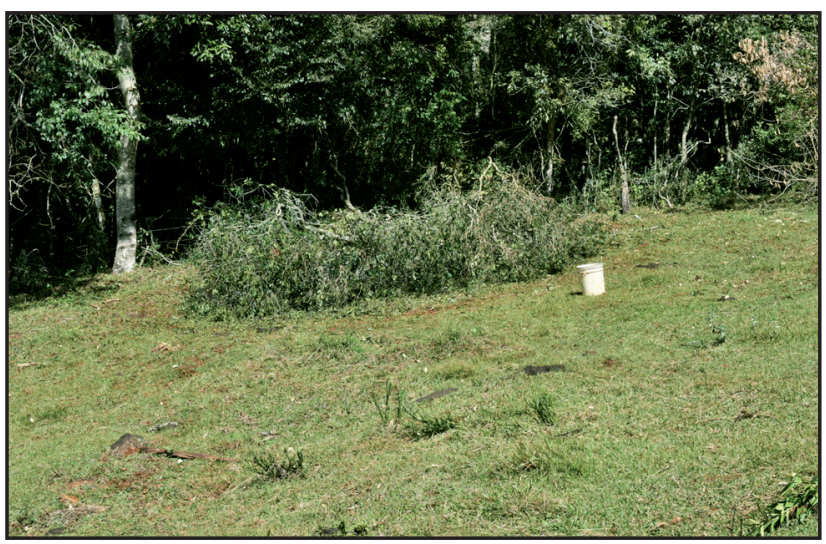

Figure 1. Hydrocyanic acid poisoning in cattle. Environment. Pasture contamination by Prunus sp. broken tree branch.

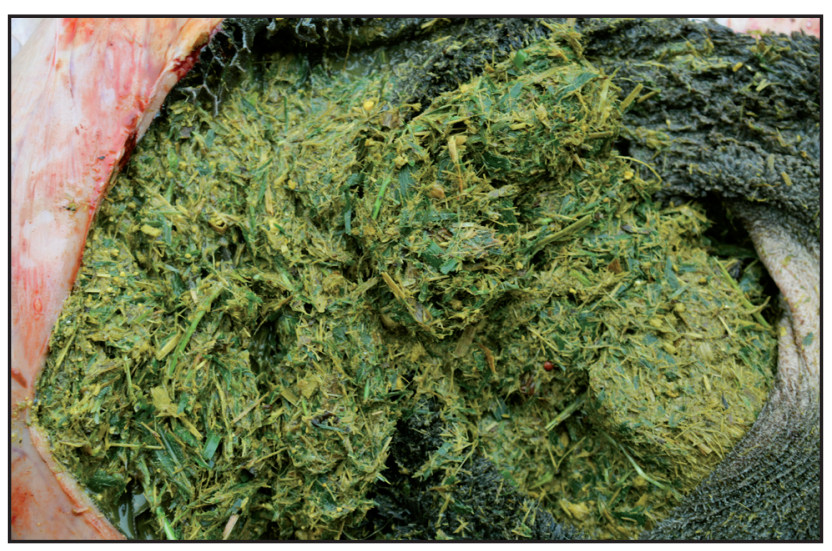

Figure 2. Hydrocyanic acid poisoning in cattle. Rumen. Unchewed and undigested Cynodon dactylon cultivar Florakirk grass mixed in the ruminal content.

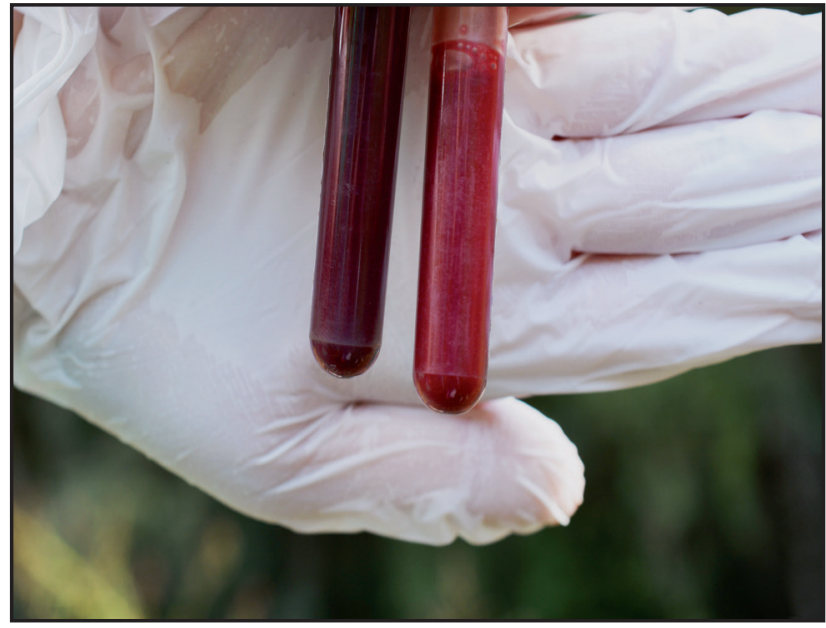

Figure 3. Hydrocyanic acid poisoning in cattle. Blood. Normal venous clotted blood (left) and non-clotting bright red venous blood (right).

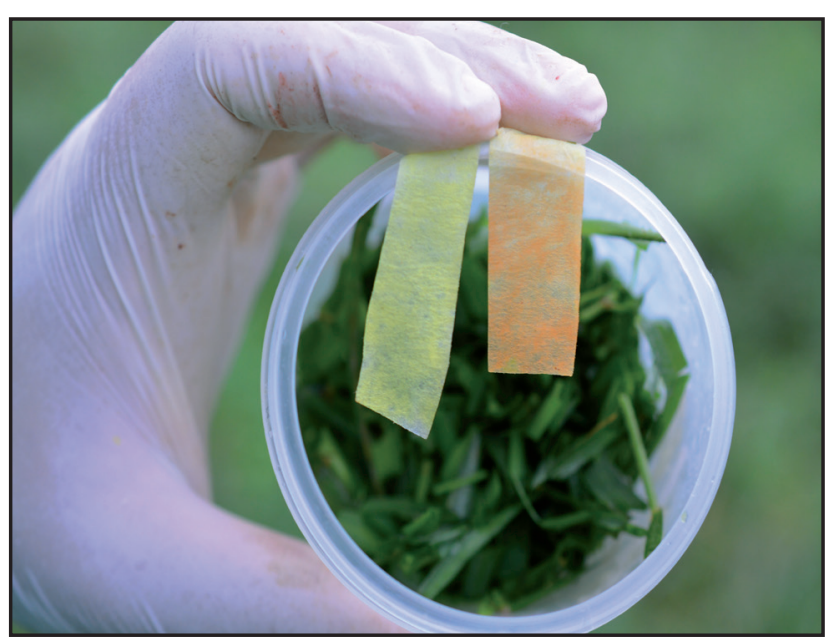

Figure 4. Hydrocyanic acid poisoning in cattle. Picrosodic paper test. Control (left) and red brick color, positive for HCN (right).

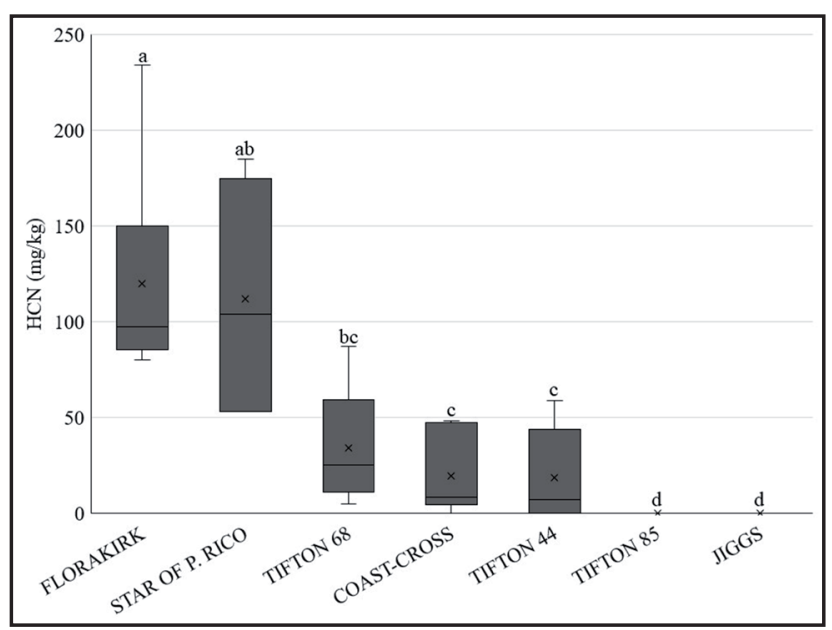

Figure 5. Amount of $\mathrm{HCN}$ present in each cultivar in the whole plant (stem and leaves). a,b,c Different letters demonstrate significant statistical difference $(P<0.05) .{ }^{x}$ Mean value among the samples of the cultivar. 


\section{DISCUSSION}

The diagnosis of hydrocyanic acid poisoning was done by associating history, clinical signs, macroscopic findings, and Picrosodic paper test results. The animals were predominantly adult, female, and dairy cattle. However, these cannot be inferred as predisposing factors. The Veterinary Pathology Laboratory is in a geographic area predominated by small dairy farms, therefore the laboratory routine activity is mainly represented by this category of animals [7].

The amount of plant capable of poisoning an adult bovine was described experimentally as $3.5 \mathrm{~g} /$ $\mathrm{kg}$ of Prunus sp. [10], $5 \mathrm{~g} / \mathrm{kg}$ of Manihot sp. [6], and $10.3 \mathrm{~g} / \mathrm{kg}$ of Tifton 68 [9]. These doses could trigger clinical signs and, in some cases, cause death. Considering that the cyanogenic plants have small poisonous doses, and the animals usually ingest large quantities of the plant, the clinical course is normally fast, explaining why farmers often found dead animals near the plants.

Considering that the Tifton 68 cultivar was described as toxic, triggering clinical signs with a dose superior to the aforementioned [9], an animal with a weight of $600 \mathrm{~kg}$ would have to ingest $6.18 \mathrm{~kg}$ of pasture. Therefore, considering our result that Tifton 68 presents $34.17 \mathrm{mg}$ of $\mathrm{HCN}$ in $1 \mathrm{~kg}$ of plant, the animal must ingest $211.17 \mathrm{mg}$ of $\mathrm{HCN}$ to be poisoned. The amount of HCN determined for each cultivar allowed the calculation of the amount of plant necessary to poison a $600 \mathrm{~kg}$ animal with each cultivar. The amount of Florakirk is $1.76 \mathrm{~kg}$, Star of Puerto Rico is 1.89 $\mathrm{kg}$, Tifton 68 is $6.18 \mathrm{~kg}$, Coast-Cross is $10.74 \mathrm{~kg}$, and Tifton 44 is $11.31 \mathrm{~kg}$. The amount necessary for each cultivar indicates the high risk of Florakirk and Star of Puerto Rico cultivars.

The factors that influence the poisoning are toxicity and speed of ingestion [13]. Furthermore, when the lethal dose is not ingested, the animal metabolizes the HCN, which causes mild clinical signs of toxicity followed by recovery [9]. Thus, not all animals in the evolve to death in some outbreaks.

Clinical signs of the poisoning are hard to observe since the clinical course of poisoning takes minutes to few hours [5]. In one of the outbreaks diagnosed, the clinical course was of $3 \mathrm{~h}$. However, in experimental poisoning with cyanogenic plants, the clinical signs began between 10 and 49 min after ingestion and evolved to death in $30 \mathrm{~min}$ to $3 \mathrm{~h}$, varying according to the dose $[6,9]$.

The pasture base or contamination of the pasture by cyanogenic trees was the most frequent mode of poisoning. Many Cynodon dactylon are already described as having potential for hydrocyanic acid poisoning [21]. However, according to the best of our knowledge, this is the first report of 2 outbreaks of spontaneous HCN poisoning by the Cynodon dactylon cultivar Florakirk, which caused the death of $8(28.6 \%)$ bovines in a total of 28 diagnosed with $\mathrm{HCN}$ poisoning, among the 1,235 $(0.65 \%)$ bovines necropsied. The Star of Puerto Rico cultivar presented a higher average level of $\mathrm{HCN}$ when compared with Tifton 68 . This last cultivar is well known to cause $\mathrm{HCN}$ poisoning among farmers, veterinarians, agronomists, and animal scientists. Moreover, Florakirk and Star of Puerto Rico cultivars were commonly found in farms in southern Brazil, making it necessary to communicate this high risk.

Other authors also observed the macroscopic findings of unchewed leaves mixed in ruminal content $[9,13,15]$. Furthermore, one case showed samples of Manihot esculenta shell. The shell is not a commonly toxic part of the plant but has been described to contain and release HCN [18].

The post mortem examination detected an evident bitter almond odor in the ruminal content in some cases, as well as petechial or ecchymotic and subepicardial hemorrhage in the tracheal mucosa, characteristics described in literature $[17,19]$. These hemorrhages are common and nonspecific lesions caused in the peri mortem period, and should not be considered as a characteristic lesion of any pathology. One case showed that the venous blood did not clot and was bright red, which occurs due to the presence of oxygen in the erythrocytes, marking the arterial and venous blood with these characteristics [4].

The Picrosodic paper test, indicating the presence of cyanogenic glycosides, is considered positive when the yellow color of the Picrosodic solution becomes brick-red, and can be performed in the chopped pasture or ruminal content [3]. The Picrosodic paper test was performed in 24 cases in this work, showing positive results for ruminal content and pasture $(75 \%)$ or only the pasture $(25 \%)$. This difference occurred because HCN is highly volatile and can be released from the ruminal content from the time of death to the post mortem examination. 
Moreover, 4 of the cases tested positive in muscles, corroborating the findings in the literature, which reported the detection of $\mathrm{HCN}$ in muscle and liver samples as a suspicion of hydrocyanic acid poisoning [19].

Differential diagnosis of hydrocyanic acid poisoning in cattle can include other conditions with rapid death such as Amorimia exotropica (not described in west of Santa Catarina), Nerium oleander (not present in any of these farms), and nitrate-nitrite poisoning (dark brown blood not seen in any of these cases). Other diseases with hyper acute or acute behavior such as anthrax, electrocution, and ruminal blot by excessive ingestion of leguminous plants are suspected [13]. Characteristic lesions are usually found in the last three.

Determination of the concentration of $\mathrm{HCN}$ in different cultivars of the Cynodon genus revealed a $\mathrm{HCN}$ concentration of 53 to $185 \mathrm{mg} / \mathrm{kg}$ in Star of Puerto Rico (mean of $111.7 \mathrm{mg} / \mathrm{kg}$ ), which is lower than the maximum level already described, $757.8 \mathrm{mg} / \mathrm{kg}$ [2]. On the other hand, Florakirk presented a mean of $119.7 \mathrm{mg} /$ $\mathrm{kg}$, with a variation of 80 to $234 \mathrm{mg} / \mathrm{kg}$ of $\mathrm{HCN}$, a much higher value than the maximum already described, 68.4 $\mathrm{mg} / \mathrm{kg}$ [22]. Data regarding the levels of $\mathrm{HCN}$ in the other cultivars were not found for comparison.

Statistically, Tifton 68 showed the highest levels of $\mathrm{HCN}(34.2 \mathrm{mg} / \mathrm{kg} \pm 30.06)$ compared with Tifton 44 (18.7 mg/kg \pm 24.6$)$, Coast-Cross (19.7 mg/ $\mathrm{kg} \pm 21.8)$, Tifton $85(0 \mathrm{mg} / \mathrm{kg})$, and Jiggs $(0 \mathrm{mg} / \mathrm{kg})$. Tifton 44 and Coast-Cross released some HCN levels, requiring precaution when used as animal feed. Tifton 85 and Jiggs on the other hand, can be used without risk of hydrocyanic acid poisoning.

Factors such as precipitation, growth, climate, and nitrogen fertilization favor the concentration of $\mathrm{HCN}$ in the plant [20]. Moreover, the concentration of HCN declines with plant aging [22]. Excessive fertilizing can also cause an excessive amount of $\mathrm{HCN}$ in the plant. Since all cultivars were subjected to the same fertilization protocol, soil, weather, among other factors, comparison was possible among all cultivars tested.

Florakirk and Star of Puerto Rico Cultivars presented higher levels of HCN compared with other cultivars. Additionally, it is common for farmers in the state of Santa Catarina to subject the pasture to a much more excessive fertilization than the one practiced in the agrostological field of the IFC, especially with manure. Thus, one can presume that the cultivars received much more nitrogen in the farms compared to the IFC.
The results of different parts of the plants showed that the leaf presented a statistically higher concentration of HCN compared with the stem and in natura plant of the Cynodon genus. This corroborates studies conducted with Sorghum vulgare Pers. [14]. The higher concentration of $\mathrm{HCN}$ in the leaves can be associated with a mode of defense that the plant develops against ingestion by animals [3].

None of the cultivars showed detectable concentrations of $\mathrm{HCN}$ when the hay was evaluated, which is explained by the fact that the haymaking process is culminates in low availability of water, decreasing the concentration of cyanogenic glycosides thereby slowing or stopping the biochemical reactions [9]. However, some works have reported that even though the Picrosodic paper test on hay showed slow or no reaction, poisoning can still occur since the ruminal bacteria can hydrolyze the low concentration of the cyanogenic glycosides [1].

\section{CONCLUSIONS}

Hydrocyanic acid poisoning in cattle is an important cause of death, and can lead to great economic losses to producers. The present study is the first description of spontaneous HCN poisoning by Cynodon dactylon cultivar Florakirk. Of all Cynodon cultivars evaluated, Florakirk is the most dangerous for animals, followed by Star of Puerto Rico and Tifton 68 cultivars, both with similar values. Both cultivars are commonly cultivated in many farms in southern Brazil and the poisoning risk they poses is still ignored.

Tifton 85 and Jiggs cultivars released no HCN and are considered safe for use as pasture. The leaves are the part of the plant with the highest concentrations of HCN. When the hay of all the cultivars was analyzed, $\mathrm{HCN}$ was not found in any, and are thus considered safe for use as animal feed. However, it is still unclear if there is an environmental or management procedure of the pasture that can predispose higher concentration of cyanogenic glycosides and induce cattle poisoning.

\section{MANUFACTURERS}

${ }^{1}$ CRQ Produtos Químicos Eirelli. Diadema, SP, Brazil.

${ }^{2}$ EasyPath - Diagnostics. São Paulo, SP, Brazil.

${ }^{3}$ Control Lab Comércio de Produtos para Laboratório Ltda. São José dos Pinhais, PR, Brazil.

${ }^{4}$ Labimpex Indústria e Comércio de Produtos para Laboratórios Ltda. Diadema, SP, Brazil.

${ }^{5}$ Statistical Analysis System (SAS) Institute Incorporate. Cary, NC, USA. 
Funding. This work was supported by grants from the Instituto Federal Catarinense (IFC) and from the Conselho Nacional de Desenvolvimento Científico e Tecnológico (CNPq).
Declaration of interest. The authors report no conflicts of interest. The authors alone are responsible for the content and writing of the paper.

\section{REFERENCES}

1 Amorim S.L., Medeiros R.M.T. \& Riet-Correa F. 2006. Intoxication by cyanogenic plants in Brazil. Ciência Animal. 16(1): 17-26.

2 Andrade C.M.S., Hessel C.E. \& Valentim J.F. 2009. Valor nutritivo e fatores antinutricionais nos capins estrelaafricana, Tangola e Tanner-grass nas condições ambientais do Acre. Amazônia: Ciência \& Desenvolvimento. 4(8): 273-283.

3 Bosak P.A., Lustosa S.B.C. \& Sandrini J.M.F. 2017. Bovine intoxication by cyanogenic acid and nitrite/nitrate in pastures of intense management. Pubvet. 11(10): 1008-1014. DOI:< https://doi.org/10.22256/PUBVET.V11N10.1008$1014>$

4 Broll, F., Bavaresco L.H., Piva M.M., Carneiro D.C.S., Gris A., Cechin R.A., Werlang R.A., Gimenes I., Chiocca R., Gomes T.M.A., Casagrande R.A. \& Mendes R.E. 2018. Intoxicação por ácido cianídrico no alto uruguai catarinense: estudo retrospectivo (2013-2017). Boletim de Diagnóstico do Laboratório de Patologia Veterinária. 2(1): 51-60. DOI: <https://doi.org/10.21166/bdpatvet.v2i1.518>

5 Câmara A.C.L., Dalcin L. \& Soto-Blanco B. 2014. Pathogenesis, clinical signs and epidemiology of the poisoning by cyanogenic plants in the Brazilian northwest. Semina: Ciências Agrárias. 35(4): 1961-1972. DOI: <https://doi. org/10.5433/1679-0359.2014v35n4p1961>

6 Canella C.F.C., Döbereiner J. \& Tokarnia C.H. 1968. Intoxicação experimental pela "Maniçoba" (Manihot glaziovii Muell. Arg.) em bovinos. Pesquisa Agropecuária Brasileira. 3(1): 347-350.

7 Carneiro C., Schwertz C.I., Henker L.C., Rhoden L.A., Piva M.M., Gabriel M.E., Lucca N.J., Baldi K.R.A., Casagrande R.A., Gomes T.M.A. \& Mendes R.E.M. 2018. Doenças diagnosticadas pelo laboratório de patologia veterinária no quinquênio 2013-2017. Boletim de Diagnóstico do Laboratório de Patologia Veterinária. 2(1): 33-48. DOI: <https://doi.org/10.21166/bdpatvet.v2i1.516>

8 Francisco I.A. \& Pinotti M.H.P. 2000. Cyanogenic glycosides in plants. Brazilian Archives of Biology and Technology. 43(5): 487-492. DOI: <https://doi.org/10.1590/S1516-89132000000500007>

9 Galindo C.M., Hemckmeier D., Biondo N., Parizotto L.H., Ogliari D. \& Gava A. 2017. Intoxicação espontânea e experimental por tifton 68 (Cynodon nlemfuensis Vanderyst) em bovinos. Pesquisa Veterinária Brasileira. 37(5): 441446. DOI: <http://dx.doi.org/10.1590/s0100-736x2017000500003>

10 Gava A., Pilati C., Cristani J., Simões J. \& Simões L. 1998. Intoxicação cianogênica em bovinos alimentados com Tifton (Cynodon sp.). In: Anais VIII Ciclo de Atualização em Medicina Veterinária (CAMEV)-UDESC (Lages, Brazil). p.119.

11 Haque M.R. \& Bradbury J.H. 2002. Total cyanide determination of plants and foods using the picrate and acid hydrolysis methods. Food Chemistry. 77(1): 107-114. DOI: <https://doi.org/10.1016/S0308-8146(01)00313-2>

12 Huzar T.F., George T. \& Cross J.M. 2013. Carbon monoxide and cyanide toxicity: etiology, pathophysiology and treatment in inhalation injury. Expert Review of Respiratory Medicine. 7(2): 159-170. DOI: <http://dx.doi.org/10.1586/ ers.13.9>

13 Juffo G.D., Pavarini S.P., Wouters F., Oliveira L.G.S., Antoniassi N.A.B., Cruz C.E.F. \& Driemeier D. 2012. Spontaneous poisoning by Sorghum sudanense in dairy cattle in Rio Grande do Sul. Pesquisa Veterinária Brasileira. 32(3): 217-220. DOI: <http://dx.doi.org/10.1590/S0100-736X2012000300006>

14 Martin J.H., Couch J.P. \& Briese R.R. 1938. Hydrocyanic Acid Content of Different Parts of the Sorghum Plant. Agronomy Journal. 30(9): 725-734. DOI: <https://dx.doi.org/10.2134/agronj1938.00021962003000090003x>

15 Molossi F.A., Ogliari D., Morais R.M., Wicpolt N.S., Gheller E., Weber L. \& Gava A. 2019. Cyanogenic poisoning by spontaneous ingestion of star grass (Cynodon nlemfuensis var. nlemfuensis cv. 'Florico') in cattle. Pesquisa Veterinária Brasileira. 39(1): 20-24. DOI: <https://dx.doi.org/10.1590/1678-5150-pvb-5981>

16 Nascimento M.P.S.C.B., Nascimento H.T.S. \& Leal J.A. 2002. Comportamento de cultivares de Cynodon no Piauí. EMBRAPA-Meio Norte, Comunicado Técnico 146.3p. Available in: < https://ainfo.cnptia.embrapa.br/digital/bitstream/ CPAMN-2009-09/17159/1/CT146.pdf>. 
17 Nicholson S.S. 2012. Cyanogenic plants. In: Gupta R.C. (Ed). Veterinary Toxicology: Basic and Clinical Principles. 2nd edn. Hopkinsville: Academic Press, pp.1113-1116.

18 Oliveira N.T., Uchôa S.C.P., Alves J.M.A., Sediyama T., Albuquerque J.A.A., Souza E.D. \& Melville C.C. 2012. Hydrocyanic acid content in cassava tissues as a function of evaluation time and nitrogen fertilization. Pesquisa Agropecuária Brasileira. 47(10): 1436-1442. DOI: <https://dx.doi.org/10.1590/S0100-204X2012001000004>

19 Radostits O.M., Gay C.C., Hinchcliff K.W. \& Constable P.D. 2012. Cyanogenic glycoside poisoning (Cyanide, hydrocyanic acid). In: Veterinary Medicine: A Textbook of the Diseases of Cattle, Horses, Sheep, Pigs and Goats. 10th edn. Philadelphia: Saunders Elsevier, pp.1852-1855.

20 Tamassia L.F.M. 2000. Produção, composição morfológica, químico-Bromatológica, digestibilidade in vitro do capim de Rhodes (Chloris gayana Kunth.) em diferentes idades de crescimento. 152f. Piracicaba, SP. Dissertação (Mestrado em Ciência Animal e Pastagens) - Escola Superior de Agricultura “Luiz de Queiroz", Universidade de São Paulo.

21 Tokarnia C.H., Brito M.F., Barbosa J.D., Vargas P.V. Peixoto P.V. \& Döbereiner J. 2012. Plantas cianogênicas. In: Plantas Tóxicas do Brasil para Animais de Produção. 2.ed. Rio de Janeiro: Helianthus, pp.443-460.

22 Vieira A.C. 1998. Efeito da idade de corte sobre a produção, composição químico-bromatológica, digestibilidade in vitro e teor de ácido cianídrico de Cynodon dactylon (L.) Pers. Cv. Florakirk. 117f. Piracicaba, RS. Dissertação (Mestrado em Ciência Animal e Pastagens) - Escola Superior de Agricultura “Luiz de Queiroz”, Universidade de São Paulo.

23 Ziech M.F., Olivo C.J., Ziech A.R.D., Paris W., Agnolin C.A. \& Meinerz G.R. 2015. Nutritive value of pastures of Cynodon mixed with forage peanut in southwestern Paraná State. Acta Scientiarum. Animal Sciences. 37(3): 243-249. DOI: <https://doi.org/10.4025/actascianimsci.v37i3.26872> 